Volume 2, No. 3, September - December 2017 ISSN: 2503-4235 (p); 2503-4243 (e)

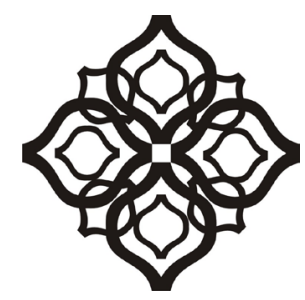

Shirkah

Journal of Economics and Business 


\section{Shirkah}

Journal of Economics and Business

Vol. 2, No. 3, September-December 2017

ISSN: 2503-4235 (p); 2503-4243 (e)

\section{Editor in Chief}

Sri Walyoto

\section{Editorial Boards}

Abu Umar Faruq Ahmad, UBD School of Business and Economics, Brunei Darussalam

Amelia Fauzia,

Asia Research Institute, National University of Singapore, Singapore

Cedomir Nestorovic,

ESSEC Business School Asia Pacific, Singapore

Dwi Condro Triono,

Faculty of Islamic Economics and Business, IAIN Surakarta, Indonesia

Fahmy Radhi,

Faculty of Economics and Business Universitas Gadjah Mada, Yogyakarta,

Indonesia

Hasan Basri,

Syiah Kuala University, Aceh, Indonesia

Johan Fischer,

Department of Social Sciences and Business Roskilde University, Denmark

Masudul Alam Choudhury,

Postgraduate Program in Islamic Economics and Finance, Trisakti University,

Jakarta, Indonesia and the College of Economics and Political Science (CEPS) in

Sultan Qaboos University (SQU), Oman

M. Falik Isbah,

School of Humanities and Social Science, University of New South Wales, Australia M. Ishaq Bhatti,

La Trobe Business School Department of Economics and Finance La Trobe

University, Australia

Najib Kailani,

Pascasarjana, Universitas Islam Negeri (UIN) Sunan Kalijaga, Yogyakarta, Indonesia 
Nunung Nurul Hidayah,

Aston Business School, Aston University, Birmingham, United Kingdom

Shaikh M Ghazanfar,

Departement of Economics, University of Idaho, Russian Federation

\section{Managing Editors}

Fitri Wulandari

Jasanta Perangin-angin

\section{Assistant to Editor}

M. Endy Saputro

M. Zainal Anwar

Supriyanto

Shirkah Journal of Economics and Business is a peer-reviewed journal published three times a year (January-April, May-August and September-December) by Faculty of Islamic Economics and Business, Institut Agama Islam Negeri (IAIN/ State Institute for Islamic Studies) Surakarta Central Java, Indonesia. The main objective of Shirkah is to offer an academic space of exchange ideas and initiate the increase number of qualified article produced by postgraduate students, practitioners and academicians.

\section{Editorial Office}

Ruang Jurnal Shirkah

Ground Floor, West Gate,

Faculty of Islamic Economics and Business

IAIN Surakarta

Jln. Pandawa No. 1, Kartasura, Sukoharjo, Jawa Tengah Kode Pos. 57168

Phone (+62271) 781516 Fax: (+62271)782336

E-mail: shirkahiainsurakarta@gmail.com

Website: http://shirkah.or.id/ 


\section{Shirkah}

Journal of Economics and Business

Vol. 2, No. 3, September-December 2017

ISSN: 2503-4235 (p); 2503-4243 (e)

\section{Table of Contents}

\section{Articles}

B.A Badejo

B.A. Okuneye

M.R Taiwo

Fraud Detection in the Banking System in Nigeria Challenges and

Prospects

Abdul Qoyum

Milzamulhaq Mardiya

Muhammad Rizky Prima Sakti

Indonesian Capital Market Efficiency: Islamic vis-a-vis Conventional

Dita Andraeny

Dessy Diana Putri

Islamicity Financial Performance Index in Indonesian Islamic Banks

Muh. Rudi Nugroho

Flypaper Effect of Regional Expenditures in Yogyakarta

Agus Faisal

Irma Yuliani

375

Productive Zakat of Baznas Yogyakarta on the Growth of Micro Business

Rakhmawati

Sakofa Evaluating Zakat Microfinance Program 


\title{
Islamicity Financial Performance Index in Indonesian Islamic Banks
}

\author{
Dita Andraeny \\ Department of Sharia Accounting \\ Faculty of Islamic Economics and Business IAIN Surakarta \\ andrayanti88@gmail.com \\ Dessy Diana Putri \\ Faculty of Islamic Economics and Business IAIN Surakarta
}

\begin{abstract}
This study aims to critically analyze the effect of islamic social reporting, intellectual capital and the sharia supervisory board on islamicity financial performance index of Islamic Banks in Indonesia during 2011-2015. The samples of this study are ten islamic commercial banks that were initially selected by using purposive sampling method. Islamicity financial performance index was used as a measure of financial performance of Islamic banks which are consist of profit sharing ratio, zakat performance ratio, equitable distribution ratio, and islamic income versus non islamic income ratio. The analysis technique performed in this study is partial least squares. The results of this research revealed that islamic social reporting, intellectual capital and sharia supervisory board have positive and significant effect on islamicity financial performance index of Islamic banks.
\end{abstract}

Keywords: islamic social reporting, intellectual capital, sharia supervisory board, islamicity financial performance index

\section{Introduction}

The development of islamic banking in Indonesia from year to year is quite well, proven by the increasing number of Islamic Commercial Banks (BUS) from 6 BUS in 2009 to 13 BUS in 2017. In addition, until January 2017, there has been 21 Islamic business unit of conventional 
banks (UUS) and 166 Islamic rural banks (BPRS). In the same period, total assets of Islamic banking is amounted Rp356,50 trillion, it is increased about $24,02 \%$ from 2016 that the assets value is still Rp287,44 trillion (OJK, 2017).

The development of Islamic banks should be accompanied by the improvement of islamic bank's performance (Meilani, et al., 2016). Muhfiatun (2016) also stated that Islamic banks are demanded to show high performance because of the strict competition in the banking industry in Indonesia. It without question is important to evaluate the islamic bank's performance. Such performance evaluation should not only be focused on financial performance, but also must ensure that islamic banks comply on islamic principles in operating their business (Anwar, 2003; Rehman and Askari, 2010).

Hameed et al (2004) proposed an alternative performance measurement for Islamic bank namely islamicity indexes that consist of islamicity disclosure index and islamicity financial performance index. This research would be focused on analyzing the factors that have significant influence on financial performance of islamic bank by using islamicity financial performance index. The previous research that analyze the performance of Islamic banks in general systematically use Return on Assets (ROA) and Return on Equity (ROE) and it still few research that use islamicity financial performance index. This measurement index is confidently able to show financial performance of islamic bank from the perspective of sharia principle.

One of the factors that is considered has significant effect on islamicity financial performance index is corporate social responsibility (CSR) disclosure. Issues concerning CSR practices in islamic banks have become increasingly important in recent years. Awareness of the importance of CSR practices encourages business entities to conduct CSR 
reporting in their annual report. There are several studies related to the CSR dislosure of islamic bank such as the research conducted by Fitria and Hartanti (2010) and also Andraeny (2016). The further studies conducted by Platonova, et al. (2016) and Arshad, et al. (2012) indicates that the level of disclosure of social responsibility able to affect the company's financial performance. On the contrary, the studies conducted by Wardani (2015) and also Reskino and Sidik (2016) show that the disclosure of social responsibility had no significant effect on financial performance. This research analyze CSR disclosure of islamic bank from sharia perspective which is recognized as islamic social reporting.

Besides islamic social reporting, islamic bank also needs to improve its strategy to increase the bank's performance, in this case islamicity financial performance. According to Sawarjuwono and Kadir (2003), islamic bank needs to change the pattern of company management from the pattern of management based on labor performance (labor based business) into a knowledge based business. Knowledge based management patterns encourage companies to effectively manage intellectual capital (Khasanah, 2016). Intellectual capital is part of intangible assets, which if managed properly will create more value in a company (Prastya, 2013). According to the Organization for Economic Cooperation and Development (OECD) (Khasanah, 2016), intellectual capital is a salient asset for companies in creating value and adding value. Puspitosari (2016), Khasanah (2016) and Ulum (2008) states that intellectual capital has a positive effect on financial performance. It shows that intellectual capital will create value added which will improve company performance. While Santoso (2012), Nurhudha and Suwarti (2014) stated that there is no positive influence of intellectual capital of a company on its performance.

The other variable that is considered has significant effect on financial performance is the implementation of corporate governance. 
Corporate governance is also important in contributing to the company's performance (Prastya, 2013). The implementation of good corporate governance serves to anticipate various risks, both financial risk and reputation (Agustianto, 2011 in Satifa and Suprapto, 2014). Without effective corporate governance implementation, islamic banks will be difficult to strengthen their position, expand their networks, and demonstrate their performance more effectively (Syukron, 2013).

According to Baehaqi (2014), the practice of implementing corporate governance in islamic banks must comply with sharia principles (sharia compliance). To guarantee the fulfillment of sharia principles in islamic banks, the roles of sharia supervisory board (SSB) become tremendously important. Baehaqi (2014) also quotes that there are at least three reasons why SSB plays an important role in developing islamic banks, namely determines the level of credibility of islamic bank, the main role in creating compliance with sharia principles, and one of the pillars of corporate governance of islamic bank. Prior researchers, such as Mollah and Zaman (2015) and Prastya (2013), have proven that GCG implementation has positive influence on financial performance of a company. Nevertheless, different result shown by the study of Supatmi (2007), which states that corporate governance have no effect on financial performance.

Previous research found that there are several variables that influence the performance of Islamic banks such as corporate social responsibility (CSR) disclosure (Sidik and Reskino, 2016, Platonova, 2016), intellectual capital (Al-Musali, et al., 2014; Ousama and Fatima, 2015), and sharia Supervisory board (Mollah and Zaman, 2015). Platonova, et al. (2016) analyzes the impact of corporate social responsibility (CSR) disclosure and financial performance of islamic banks in GCC country. The result of this research show that there is significant and positive correlation between CSR disclosure and financial performance of islamic bank. 
The study of Al-Musali, et al. (2014) attempts to examine the impact of intellectual capital on financial performance of the banks in Saudi Arabia. The results show that VAIC influence financial performance. Meanwhile, the research of Ousama and Fatima (2015) analyzes the relationship of intellectual capital and financial performance of islamic banking in Malaysia. The conclusion of this research finds that intellectual capital and its components have significant influence on the profitability of islamic banks. Budiasih (2015) empirically tested the influence of intellectual capital and CSR on the profitability of the banking sector. The results of this study indicate that intellectual capital has positive effect on profitability. So that, the intellectual capital component contributes to the bank's ability to improve financial performance. Increased ROA will lead to increased financial performance that can have a positive impact on returns obtained by stakeholders. On the other hand, CSR has no effect on profitability. In addition,

Prastya (2013) examines the influence of intellectual capital and corporate governance on financial performance. The results show that intellectual capital and corporate governance affect the financial performance. This indicates that the company considers investments in intangible assets will increase the profitability of the company. Furthermore, the companies that have implemented corporate governance will be more trusted for creditors and investors. In addition, the research done by Puspitosari (2016) examines the influence of intellectual capital components on financial performance. The results of this study indicate that the component of intellectual capital has positive and significant influence on financial performance.

Mollah and Zaman (2015) examines whether sharia supervisory board (SSB) as the foundation of corporate governance of islamic banking is able to create better shareholder value. The result of this study indicates 
that SSB has positive effect on the performance of Islamic banks. This research argue that islamic social reporting, intellectual capital, and sharia supervisory board have significant influence on islamicity financial performance index of islamic banks during 2011-2015 period.

\section{IFPI, ISR, Intellectual Capital and SSB}

Islamicity Financial Performance Index (IFPI) is a performance measurement tool that is able to show materialistic and spiritual values of islamic bank (Meilani, et al., 2016: 27). Performance measurement by using islamicity financial performance index is based on the information disclosed in annual report of the bank. Hameed, et al. (2014) uses seven financial ratios in financial performance measurement methods for Islamic banks, as follows:

Profit Sharing Ratio (PSR); profit sharing transaction such as mudharaba and musharaka considered as the core of sharia banks. Profit sharing ratio is used to measure how much islamic bank focuses on its business core through distributing funds to the productive sector by using profit sharing scheme (Hameed, et al., 2004). The valuation of the profit sharing ratio is based on the amount of profit-sharing financing divided by the overall financing. Zakat Performance Ratio (ZPR); the performance of islamic banks should be based on the payment of zakat paid by the bank (Hameed, et al., 2004: 19). The formulation of ZPR divides the amount of zakat paid by islamic bank with net assets of the bank. Equitable Distribution Ratio (EDR); this ratio is basically trying to find out how the income earned by islamic banks is distributed to various stakeholders (Hameed, et al., 2004: 19). In this case, it can be seen from the amount of money spent on qard and donations, the cost of employees, and others (Meilani, et al., 2016: 28). The ratio of ZPR is obtained by dividing the amount of average distribution for each stakeholder with total revenue. 
Directors - Employees Welfare Ratio; directors - employees welfare ratio identifies the amount of money used for directors and the amount of money for employee welfare (Hameed, et al., 2004: 19). Employee welfare includes salaries, training, etc (Meilani, et al., 2016: 28). The formula of directors-employees welfare ratio is obtained by dividing directors' salary with the amount of money spent for employees welfare. Islamic Investment versus Non-Islamic Investment; this indicator explains the ratio comparing halal investment to total investments made by Islamic banks as a whole (halal and non-halal) (Hameed, et al., 2004: 19). The value resulted is a measure of halal aspects and the successful implementation of the basic principles of Islamic banks, which are free from elements of maysir, gharar, and usury in terms of investment (Meilani, et al., 2016: 28).

Islamic Income versus Non-Islamic Income; this ratio aims to measure income derived from halal income (Hameed, et al., 2004: 20). The Islamic principle prohibits the existence of non-halal transactions (usury, gharar, and maysir) and obliges the halal trade (Khasanah, 2016: 4). Therefore, it is important for sharia banks to honestly disclose any earnings perceived as halal, and where non-halal income (Hameed, et al., 2004: 20). AAOIFI Index; this index measures how far sharia banking complies with the principles established by AAOIFI (Accounting and Auditing Organization for Islamic Financial Institutions) (Hameed, et al., 2004: 20). From seven measurement indicators of islamicity financial performance above, this research is only uses four indicators namely profit sharing ratio (PSR), zakat performance ratio (ZPR), equitable distribution ratio (EDR), and islamic income vs non islamic income ratio. Meanwhile, the other indicators are not used because the data needed to calculate such ratios are not available in the annual report of islamic banks that become the samples of this research.

The research relate to CSR disclosure in Islamic banks generally use the Islamic Social Reporting index model (ISR index) developed 
on the basis of reporting standards from the Accounting and Auditing Organization for Islamic Financial Institutions (AAOIFI). Researchers who developed the ISR were Haniffa (2002), Maali (2006), and Othman, et al. (2009), for whom uses the ISR index which is an adaptation of Haniffa's research (2002) and Othman, et al. (2009) which consists of the following six themes: finance and investment, products and services, labor, society, environment, and corporate governance.

Ulum (2013: 188) defines "intellectual capital is the sum of everything in your company. It is intellectual material-knowledge, information, intellectual property, experience - that can be put to use to create wealth." In terms of measurement, VAIC ${ }^{\mathrm{TM}}$ is one of the tool to measure the intellectual capital performance of a company by calculating the company's ability to create value added (Haniyah and Priyadi, 2014: 5). According in Santoso (2012: 16), value added is the most objective indicator to assess business success and show the company's ability in value creation. VAIC ${ }^{\mathrm{TM}}$ consists of three main components that can be seen from the company's resources, namely (Santoso, 2012):

1. Value Added Capital Employed (VACA)

Value Added Capital Employed (VACA) is the ratio between value added (VA) and physical capital used (capital employed). VACA is a Value Added indicator created by a unit of physical capital (Ulum, 2013: 9). VACA describes how much added value the company generated from the physical capital used (Ulum, 2009: 79).

2. Value Added Human Capital (VAHU)

Value Added Human Capital (VAHU) indicates how much value added (VA) can be generated with the funds spent on employee labor (Kuryanto and Syafruddin, 2009: 134). The relationship between value added and human capital ( $\mathrm{HC}$ ) indicates the ability of $\mathrm{HC}$ to 
create value within the firm (Puspitosari, 2016: 46). In the calculation of VAIC ${ }^{\text {TM }}$, HC is calculated through employees' expenses (Soemarso, 2004: 55).

\section{Structural Capital Value Added (STVA)}

Structural Capital Value Added (STVA) shows the contribution of structural capital (SC) in value formation (Kuryanto and Syafruddin, 2009: 134). The STVA measures the amount of structural capital (SC) required to generate one rupiah from the value added (VA) and is an indication of how SC's success in value creation (Puspitosari, 2016: 46).

The iB-VAIC ${ }^{\text {TM }}$ method was developed by Ulum (2013) modifying the Pulic (1998) model known as VAIC ${ }^{\mathrm{TM}}$. The method of $\mathrm{VAIC}^{\mathrm{TM}}$ measures intellectual capital of conventional company (private sector, profit motive, non syariah) while iB-VAIC ${ }^{\mathrm{TM}}$ method measure intellectual capital (IC) in islamic banking in Indonesia. The other difference is in the accounts calculating value added (Wahyuni and Pujiharto, 2015: 102). The accounts develops the value added formula in the Pulic model (1998) are constructed from total revenue. Meanwhile, the value added in the Ulum's model (2013) is constructed from all sharia-compliant revenue accounts. The income account is the net income of sharia activities and non-operational sharia income. Ulum (2013) formulated the calculation method of intellectual capital by using iB-VAIC ${ }^{\mathrm{TM}}$ method. This method is measured by value added that is generated from the sum of Islamic Banking Value Added Capital Employed (iB-VACA), Islamic Banking Value Added Human Capital (iB-VAHU), and Islamic Banking Structural Capital Value Added (iB-STVA) (Ulum, 2013: 19).

According to Bank Indonesia Regulation (PBI) No. 11/33/ $\mathrm{PBI} / 2009$, SSB has been a board that the duties are providing advice 
to the directors and supervising bank activities to ensure that the bank's operation is in accordance with sharia principles (OJK, 2017). In the Act No. 21/2008 on islamic banking, in the article 32, verse 1 states that SSB must be established in an islamic bank and conventional bank which has sharia business unit (Bank Indonesia, 2017). The provisions on membership of SSB are regulated in PBI No. 15/13/PBI/2013 concerning the amendment to Bank Indonesia Regulation (PBI) No.11/3/PBI/ 2009 concerning sharia commercial banks in the second part of Article 36 states that the number of SSB members is at least 2 (two) persons and maximum $50 \%$ from the number of the board of directors' members. SSB can concurrently occupy as sharia supervisory position in 4 (four) islamic financial institutions (Bank Indonesia, 2017)

\section{Hypothesis Development}

Disclosure of social responsibility is the disclosure of information related to corporate social responsibility activities. The disclosure of social responsibility in Islamic banks is measured by the Islamic Social Reporting (ISR) proxy as it describes social activity according to the Islamic view (Firmansyah, 2014: 55). The Disclosure of ISR able to make the customer pay attention to the social contribution that has been done by islamic bank to society. If the level of corporate social disclosure is wide, it will encourage customers to use the services of the bank. This is because the customers assess that islamic bank has been responsible to the community by doing a lot of social activities and has transparently disclosed its social activities.

It can be concluded that social awareness of companies and the disclosure of social information done by them, can become a competitive advantage for those companies that will affect the companies' performance (Yaparto, et al., 2013). Islamic banks are expected to not only pursue profit 
factors but only attempt to realize the responsibility as caliphs on earth (Wardani, 2015). Platonova, et al (2016) proves that the disclosure of social responsibility can affect the financial performance of the company. The more complete and comprehensive disclosure of social responsibility, then the company's profitability increases. This is in line with with the research done by Arshad et al (2012) which shows that CSR disclosure of Islamic concept has positive influence on company performance. Thus, the hypothesis in this study is

\section{$H_{1}$ : Islamic Social Reporting has positive and significant influence on islamicity financial performance index of islamic bank}

Intellectual capital (IC) is a resource that plays an active role in the creation of corporate value, so that IC plays an important role in creating and maintaining competitive advantage (Widyaningdyah and Aryani, 2013:4). According to Chen, et al. (2005) IC contribute in increasing competitive advantage through the creation of value from measurable resources (Haryanto and Syafruddin, 2013: 2). Companies that are able to innovate continuously through learning can adapt to a dynamic business environment. IC is the main capital for the formation of innovation and learning so that the company is able to continue to survive in high business competition. Thus, IC not only required the company to survive but also able to achieve superior performance (Widyaningdyah and Aryani, 2013:4). By using the iB-VAIC ${ }^{\mathrm{TM}}$ formula, the performance of intellectual capital in islamic banking can be measured. The results of these measurements can be an indication for decision makers about how companies manage their owned ICs to maximize value added for the company. This is in line with Puspitosari (2016), Khasanah (2016) and Ulum (2008) which show that intellectual capital has positive effect on the company's financial performance. If a company manages its intellectual capital properly then 
it will have value added that can create a competitive advantage for the company. Thus, the hypothesis of this research is:

\section{$\mathrm{H}_{2}$ : Intellectual capital has positive and significant influence on islamicity financial financial performance index of Islamic bank.}

One of the fundamental differences between conventional and Islamic bank's organization structure is the obligation to appoint sharia supervisory board (SSB) in Islamic bank (Satifa and Suprapto, 2014). The duty of SSB is controlling all bank activities in order to ensure that the bank comply with sharia principles. SSB is an important part of the implementation of good corporate governance (GCG) in Islamic banking. With the existence and good characteristics of sharia supervisory board, the mechanism of supervision of Islamic bank management will be better (Dewayanto, 2010). Thus, the better the characteristics of sharia supervisory board, the supervision of Islamic bank activities will increase. This is able to encourage Islamic bank's management to more comply on sharia principles in operating the bank. Therefore, it can minimize the possibility of fraud done by Islamic bank's management that are able to decrease the bank's performance. It means, sharia supervisory board can increase Islamicity financial performance. Mollah and Zaman (2015) proved that sharia supervisory board has positive effect on financial performance of Islamic bank. In line with this, the hypothesis of this study is: 


\section{$\mathrm{H}_{3}$ : Sharia supervisory board has positive and significant influence on islamicity financial performance index of Islamic bank.}

Figure 1. Research Model

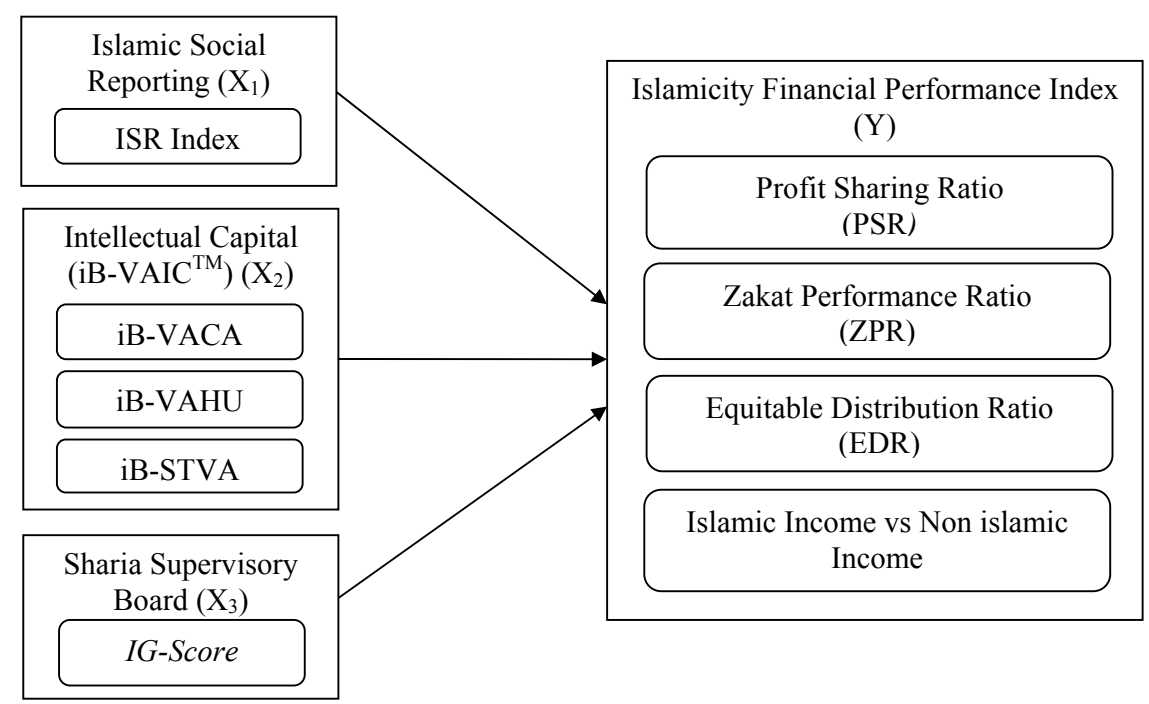

\section{Research Design}

This research analyzed the data from annual report of Islamic Commercial Bank (BUS) during 2011-2015 period. The population of this study are all Islamic Commercial Banks in Indonesia. Based on Islamic banking statistics, until August 2016 there are 12 Islamic Commercial Banks in Indonesia. Sampling method used in this study is purposive sampling, that determine the samples based on 2 criteria: (1) Islamic commercial bank that has been operating nationally during the research period (2011-2015); (2) Islamic commercial bank that published annual report completely during 2011-2015. From 12 Islamic commercial banks (BUS), there are 10 banks that meet the specified criteria. The list of islamic banks' name that used as the samples of this study are explained on the table 1 below. 
Table 1. Research Sample

\begin{tabular}{|c|l|c|}
\hline No. & \multicolumn{1}{|c|}{ Name of Islamic Banks } & Code \\
\hline 1. & PT. Bank Muamalat Indonesia & BMI \\
\hline 2. & PT. Bank Syariah Mandiri & BSM \\
\hline 3. & PT. Bank BRI Syariah & BRIS \\
\hline 4. & PT. Bank BNI Syariah & BNIS \\
\hline 5. & PT. Bank Mega Syariah & BMS \\
\hline 6. & PT. Bank BCA Syariah & BCAS \\
\hline 7. & PT. Bank Bukopin Syariah & BSB \\
\hline 8. & PT. Bank Panin Syariah & BPS \\
\hline 9. & PT. Maybank Syariah Indonesia & BMSI \\
\hline 10. & PT. Bank Victoria Syariah & BVS \\
\hline
\end{tabular}

Data analysis used in this research is partial least square (PLS). Islamicity Financial Performance Index is used to measure the performance of islamic bank. This measurement was developed by Hameed, et al. (2004). In addition, islamic social reporting variable is measured by ISR index. The ISR index used in this study is an adaptation of the ISR index developed by Haniffa (2002) dan Othman, et al. (2009) with several adjustments. The ISR index is measured by using the content analysis method. The analysis is done by comparing each item that should be disclosed based on the ISR index with actual disclosure in the annual report of islamic bank. The ISR index is consist of 6 indicators which are developed into 46 disclosure items. The value of 1 is given for each item disclosed, and the value 0 for each undisclosed item.

Meanwhile, intellectual capital (IC) is measured by using iBVAIC $^{\mathrm{TM}}$ (islamic Banking-Value Added Intellectual Coefficient) which was developed by Ulum (2013) to measure intellectual capital of islamic bank in Indonesia. iB-VAIC ${ }^{\mathrm{TM}}$ indicates intellectual capability of islamic bank which is the sum of iB-VACA (islamic Banking-Value Added Capital Employed), iB-VAHU (islamic Banking-Value Added Human Capital), 
dan iB-STVA (islamic Banking-Structural Capital Value Added). Sharia supervisory board (SSB) variable is measured by Islamic Governance (IG) score developed by Farook, et al. (2011). The IG-score assessment is obtained from annual reports analysis and is based on the existence and characteristics of SSB. The number of scores is assessed by using dummy variable including the existence of members of SSB, the number of SSB members, the presence of cross membership of SSB, SSB with doctoral qualifications in economics and Islamic law, and the presence of reputable scholar in SSB. The descriptions of Islamic Governance (IG) score are explained in the table 1 below.

Table 2. Islamic Governance Score

\begin{tabular}{|l|l|l|}
\hline SSB & The Existence of SSB members & $\begin{array}{l}\text { Value of } 1 \text { if the bank has SSB, } 0 \text { if } \\
\text { doesn't have }\end{array}$ \\
\hline NUM & The number of SSB & $\begin{array}{l}\text { Value of } 1 \text { if the bank has more than 7 } \\
\text { members, } 0 \text { if fewer than 7 }\end{array}$ \\
\hline CROSS & $\begin{array}{l}\text { The existence of cross } \\
\text { membership of SSB }\end{array}$ & $\begin{array}{l}\text { Value of } 1 \text { if the cross membership of } \\
\text { SSB is exist, 0 if doesn't exist }\end{array}$ \\
\hline PHD & $\begin{array}{l}\text { Doctoral qualification of SSB } \\
\text { member in Islamic Economics } \\
\text { or Islamic Law }\end{array}$ & $\begin{array}{l}\text { Value of } 1 \text { if there is SSB member } \\
\text { with doctoral qualification in } \\
\text { Economics or Islamic Law, 0 if doesn't } \\
\text { exist }\end{array}$ \\
\hline REP & $\begin{array}{l}\text { Reputable scholar of SSB } \\
\text { member }\end{array}$ & $\begin{array}{l}\text { Value of } 1 \text { if there is reputable scholar } \\
\text { in SSB, 0 if doesn't exist }\end{array}$ \\
\hline
\end{tabular}

Source: Farook, et al (2011)

\section{Outer Model and Inner Model Testing}

Analysis technique used in this research is Partial Least Squares (PLS) with two analysis phase to assess whether the research model fit or not. These two analysis are outer model or measurement model test and inner model or structural model test. 


\section{Testing Outer and Inner Model of Hypothesis 1}

The result of outer model testing can be seen in the figure 1 below.

\section{Figure 2. Outer Model of Hypothesis 1}



Sources: SmartPLS output, 2017

Based on the results of the analysis output, it can be known that only two indicators that able to form islamicity financial performance index variable which produces a significance value t-statistic > 1,96 (significance level $=5 \%$ ). Based on the Outer Weight table (table 2) it can be seen that the PSR and ZPR indicators, each of them produces t-statistic value of 2,190 and 3,966 > 1,96. Therefore, it can be concluded that the two formative indicators are valid as a measure of the construct islamicity financial performance index.

Table 3. Outer Weight of Hypothesis 1

\begin{tabular}{|c|c|c|c|c|c|}
\hline & $\begin{array}{l}\text { Original } \\
\text { Sample } \\
(\mathrm{O})\end{array}$ & $\begin{array}{l}\text { Sample } \\
\text { Mean (M) }\end{array}$ & $\begin{array}{l}\text { Standard } \\
\text { Deviation } \\
(\text { STDEV) }\end{array}$ & $\begin{array}{l}\text { T Statistics } \\
(\mid \mathrm{O} / \\
\text { STDEV|) }\end{array}$ & $\begin{array}{c}\mathrm{P} \\
\text { Values }\end{array}$ \\
\hline EDR $->$ ISLAMICITY & 0,024 & 0,005 & 0,175 & 0,134 & 0,893 \\
\hline ISR $<-$ ISR & 1,000 & 1,000 & 0,000 & & \\
\hline $\begin{array}{l}\text { Islamic Income -> } \\
\text { ISLAMICITY }\end{array}$ & $-0,164$ & $-0,171$ & 0,212 & 0,772 & 0,440 \\
\hline PSR -> ISLAMICITY & 0,515 & 0,486 & 0,235 & 2,190 & 0,029 \\
\hline ZPR $\rightarrow$ ISLAMICITY & 0,691 & 0,647 & 0,174 & 3,966 & 0,000 \\
\hline
\end{tabular}

Sources: Smart PLS output, 2017 
Table 2 above shows that there are 2 indicators namely EDR and islamic income which have t-statistic value lower than $\mathrm{t}$ table $(0,134 ; 0,772$ $<1,96)$. It means that the two indicators are not valid as a measure of islamicity financial performance variable. Therefore, it is necessary to recalculate outer model by eliminating invalid indicators and involving only valid and significant indicators.

Figure 3. Outer Model of Hypothesis 1 (recalculate)



Sources: Smart PLS output, 2017

After recalculating outer model by eliminating invalid indicators, it can be seen that the valid indicators forming islamicity financial performance index are PSR and ZPR with t-statistic value of 2,394 and 4,378 respectively, greater than 1,96 . These results are shown in the table 3 below.

Table 4. Outer Weight Hypothesis 1 (Recalculate)

\begin{tabular}{|l|c|l|c|c|c|}
\hline & $\begin{array}{l}\text { Original } \\
\text { Sample } \\
(\mathrm{O})\end{array}$ & $\begin{array}{l}\text { Sample } \\
\text { Mean } \\
(\mathrm{M})\end{array}$ & $\begin{array}{l}\text { Standard } \\
\text { Deviation } \\
(\text { STDEV })\end{array}$ & $\begin{array}{l}\text { T Statistics } \\
(\mid \mathrm{O} / \\
\text { STDEV| })\end{array}$ & P Values \\
\hline ISR <- ISR & 1,000 & 1,000 & 0,000 & & \\
\hline PSR -> ISLAMICITY & 0,472 & 0,462 & 0,197 & 2,394 & 0,017 \\
\hline ZPR -> ISLAMICITY & 0,704 & 0,694 & 0,161 & 4,378 & 0,000 \\
\hline
\end{tabular}

Sources: Smart PLS Output, 2017 


\section{Inner Model Testing}

Inner model testing of the first exogenous variable (Islamic Social Reporting) can be seen in the table 4 .

Table 5. R-Square Value of Islamic Social Reporting (ISR)

\begin{tabular}{|l|c|}
\hline & R Square \\
\hline ISR & \\
\hline ISLAMICITY & 0,341 \\
\hline
\end{tabular}

Sources: Smart PLS Output, 2017

From the results of the above output, it can be known that the value of R-Square generated is 0,341 . It means that the ISR variable is able to explain the islamicity financial performance index of $34,1 \%$. So that, the influence of ISR variable to islamicity financial performance index is equal to $34,1 \%$ and the rest $65,9 \%$ influenced by other variable outside this research model. The second test is to analyze the significance of ISR influence on islamicity financial performance index by comparing $\mathrm{t}$-statistical value and t table value. The following table presents the value of the parameter coefficients in the structural model testing.

Table 6. Path Coefficients of Hypothesis 1

\begin{tabular}{|l|l|l|c|c|c|}
\hline & $\begin{array}{l}\text { Original } \\
\text { Sample } \\
(\mathrm{O})\end{array}$ & $\begin{array}{l}\text { Sample } \\
\text { Mean } \\
(\mathrm{M})\end{array}$ & $\begin{array}{l}\text { Standard } \\
\text { Deviation } \\
(\text { STDEV })\end{array}$ & $\begin{array}{l}\text { T Statistics } \\
(\mid \mathrm{O} / \text { STDEV })\end{array}$ & P Values \\
\hline $\begin{array}{l}\text { ISR }-> \\
\text { ISLAMICITY }\end{array}$ & 0,584 & 0,597 & 0,064 & 9,107 & 0,000 \\
\hline
\end{tabular}

Sources: Smart PLS Output, 2017

According to the result of path coefficients above, it can be seen that parameter coefficients is 0,584 , it means that there is positive influence of ISR on islamicity financial performance index. So that, the wider ISR 
disclosure, the higher islamic bank's performance. In addition, t-statistic value is 9,107 > 1,96. It can be concluded that ISR variable has positive and significant influence on islamicity financial performance index. Thus, the first hypothesis is accepted.

\section{Testing of Outer Model and Inner Model of Hypothesis 2}

\section{Outer Model Testing}

The results of outer model testing generated by PLS (Partial Least Squares) are explained in the figure 2 below.

\section{Figure 4. Results of Outer Model of Hypothesis 2}



Sources: Smart PLS Output, 2017

From the output of the analysis, it can be seen that only one indicator forming $\mathrm{iB} \mathrm{VAIC} \mathrm{C}^{\mathrm{TM}}$ and one indicator forming islamicity financial performance index that produces $t$-statistic value $>1,96$. In addition, based on the results of outer weight testing in the table 6 we know that iB-VACA indicator produces t-statistic value of 2,208 > 1,96. And ZPR indicator generates t-statistic value of 2,253 > 1,96. Thus, it can be concluded that iB-VACA is valid indicator as a measure of intellectual capital construct and ZPR valid as a measure of islamicity financial performance index construct. 
Table 7. Outer Weight Testing of Hypothesis 2

\begin{tabular}{|l|c|c|c|c|c|}
\hline & $\begin{array}{c}\text { Original } \\
\text { Sample } \\
(\mathrm{O})\end{array}$ & $\begin{array}{c}\text { Sample } \\
\text { Mean (M) }\end{array}$ & $\begin{array}{c}\text { Standard } \\
\text { Deviation } \\
(\text { STDEV })\end{array}$ & $\begin{array}{c}\text { T Statistics } \\
(\mid \mathrm{O} / \\
\text { STDEV|) }\end{array}$ & P Values \\
\hline $\begin{array}{l}\text { EDR -> } \\
\text { ISLAMICITY }\end{array}$ & 0,094 & 0,086 & 0,318 & 0,294 & 0,769 \\
\hline $\begin{array}{l}\text { Islamic Income -> } \\
\text { ISLAMICITY }\end{array}$ & 0,255 & 0,196 & 0,212 & 1,201 & 0,230 \\
\hline PSR -> ISLAMICITY & $-0,038$ & $-0,043$ & 0,223 & 0,170 & 0,865 \\
\hline ZPR -> ISLAMICITY & 0,959 & 0,760 & 0,426 & 2,253 & 0,024 \\
\hline iB-STVA -> iB-VAIC & 0,144 & 0,183 & 0,392 & 0,367 & 0,713 \\
\hline iB-VACA -> iB-VAIC & 1,018 & 0,797 & 0,461 & 2,208 & 0,027 \\
\hline iB-VAHU -> iB-VAIC & $-0,256$ & $-0,265$ & 0,552 & 0,465 & 0,642 \\
\hline
\end{tabular}

Sources: Smart PLS Output, 2017

Because there are indicators that have invalid t-statistic value, so it is necessary to recalculate the outer model by eliminating invalid indicators and only involving the valid and significant indicators.

Figure 5. Outer Model Testing of Hypothesis 2 (Recalculate)



Sources: SmartPLS Output, 2017

After recalculating the outer model, it can be seen that the valid indicators are VACA and ZPR. The next step is to test the structural model or inner model to determine the effect between latent variables.

\section{Inner Model Testing}

The value of R-Square for intellectual capital variable is in the table 7 below. 


\section{Table 8. R-Square Value of Intellectual Capital}

\begin{tabular}{|l|l|}
\hline & R Square \\
\hline iB-VAIC & \\
\hline ISLAMICITY & 0,411 \\
\hline
\end{tabular}

Sources: SmartPLS Output, 2017

According to the table 7 above, it is known that the value of $\mathrm{R}$-Square generated is 0,411 which means that intellectual capital variable measured by $\mathrm{iB}_{\mathrm{BAIC}}{ }^{\mathrm{TM}}$ is able to explain islamicity financial performance index of $41,1 \%$. It can be concluded that the effect of intellectual capital on islamicity financial performance index is $41,1 \%$ and the rest $58,9 \%$ is influenced by other variables outside this research model.

The second test is to analyze the significance of intellectual capital influence on islamicity financial performance index by looking at the value of parameter coefficient and t-statistical value. The following table presents the value of the parameter coefficients in the structural model testing.

Table 9. Path Coefficients of Hypothesis 2

\begin{tabular}{|l|c|l|c|c|c|}
\hline & $\begin{array}{l}\text { Original } \\
\text { Sample (O) }\end{array}$ & $\begin{array}{l}\text { Sample } \\
\text { Mean } \\
(\mathrm{M})\end{array}$ & $\begin{array}{l}\text { Standard } \\
\text { Deviation } \\
(\text { STDEV })\end{array}$ & $\begin{array}{l}\text { T Statistics } \\
(\mid \mathrm{O} / \\
\text { STDEV|) }\end{array}$ & P Values \\
\hline $\begin{array}{l}\text { iB-VAIC -> } \\
\text { ISLAMICITY }\end{array}$ & 0,641 & 0,639 & 0,086 & 7,434 & 0,000 \\
\hline
\end{tabular}

Sources: Smart PLS Output, 2017

Based on the results of the path coefficients above can be seen that the parameter coefficient is 0,641 which means there is positive influence of $\mathrm{iB}_{\mathrm{VAIC}} \mathrm{TM}^{\mathrm{TM}}$ on islamicity financial performance index. The higher the value of $\mathrm{iB}_{\mathrm{VAIC}}{ }^{\mathrm{TM}}$ the higher the performance of islamic banks. The value of $t$-statistic is greater than $t$ table $(7,434>1,96)$. Therefore, it can be concluded that the intellectual capital variable has positive and 
significant effect on islamicity financial performance index. Thus, the second hypothesis is accepted.

\section{Outer and Inner Model Testing of Hypothesis 3}

\section{Outer Model Testing}

The results of outer model testing of third hypothesis generated by PLS (Partial Least Squares) are figured below.

Figure 6. Outer Model Results of Hypothesis 3

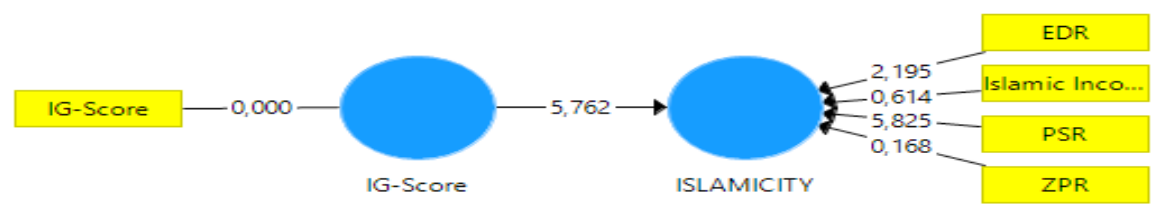

Sources: Smart PLS Output, 2017

From the results of the analysis output, it can be known that only two indicators forming islamicity financial performance index that produces the value of $\mathrm{t}$-statistic $>1,96$. Based on the Outer Weight results in the table 9, it can be seen that the EDR and PSR indicators, each of them produces t-statistic value that higher than t table (2,195 and 5,825 > 1,96). It can be concluded that the indicators of EDR and PSR are valid as a measure of islamicity financial performance index construct.

Table 10. Outer Weight Results of Hypothesis 3

\begin{tabular}{|l|c|l|c|c|c|}
\hline & $\begin{array}{l}\text { Original } \\
\text { Sample } \\
(\mathrm{O})\end{array}$ & $\begin{array}{l}\text { Sample } \\
\text { Mean } \\
(\mathrm{M})\end{array}$ & $\begin{array}{l}\text { Standard } \\
\text { Deviation } \\
(\text { STDEV })\end{array}$ & $\begin{array}{l}\text { T Statistics } \\
(\mid \mathrm{O} / \\
\text { STDEV })\end{array}$ & P Values \\
\hline EDR -> ISLAMICITY & 0,607 & 0,552 & 0,277 & 2,195 & 0,028 \\
\hline IG-Score <- IG-Score & 1,000 & 1,000 & 0,000 & & \\
\hline
\end{tabular}




\begin{tabular}{|l|c|c|c|c|c|}
\hline $\begin{array}{l}\text { Islamic Income -> } \\
\text { ISLAMICITY }\end{array}$ & $-0,093$ & $-0,091$ & 0,151 & 0,614 & 0,539 \\
\hline PSR -> ISLAMICITY & 1,023 & 0,954 & 0,176 & 5,825 & 0,000 \\
\hline ZPR -> ISLAMICITY & 0,035 & 0,038 & 0,210 & 0,168 & 0,867 \\
\hline
\end{tabular}

Sources: Smart PLS Output, 2017

Since there are indicators that have invalid t-statistic value, it is necessary to recalculate outer model by eliminating invalid indicators and involving only valid and significant indicators. The results of outer model recalculating of third hypothesis can be seen in the figure below.

Figure 7. Outer Model Results of Hypothesis 3 (Recalculate)

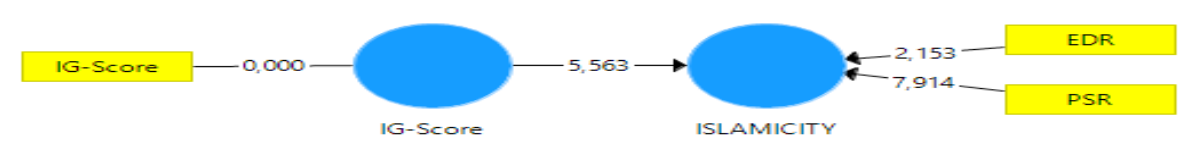

Sources: SmartPLS Output, 2017

After recalculating the outer model by eliminating invalid indicators, it is known that the valid indicators forming islamicity financial performance index are EDR and PSR. These two indicators generate t-statistic values of 2,153 and 7,914 respectively, greater than 1,96 (t-statistic > 1.96) as shown in the table 11 below.

Table 11. Outer Weight Hipotesis 3 (Recalculate)

\begin{tabular}{|l|l|l|l|l|l|}
\hline & $\begin{array}{l}\text { Original } \\
\text { Sample } \\
(\mathrm{O})\end{array}$ & $\begin{array}{l}\text { Sample } \\
\text { Mean } \\
(\mathrm{M})\end{array}$ & $\begin{array}{l}\text { Standard } \\
\text { Deviation } \\
(\text { STDEV })\end{array}$ & $\begin{array}{l}\text { T Statistics } \\
(\mid \mathrm{O} / \\
\text { STDEV } \mid)\end{array}$ & P Values \\
\hline EDR -> ISLAMICITY & 0,626 & 0,586 & 0,291 & 2,153 & 0,032 \\
\hline IG-Score <- IG-Score & 1,000 & 1,000 & 0,000 & & \\
\hline PSR -> ISLAMICITY & 1,025 & 0,991 & 0,129 & 7,914 & 0,000 \\
\hline
\end{tabular}

Sources: Smart PLS Output, 2017

Vol. 2 No. No. 3, September - December 2017 


\section{Inner Model Testing}

The following table describes the result of $R$-Square value of sharia supervisory board.

Table 12. R-Square Value of Sharia Supervisory Board (SSB)

\begin{tabular}{|l|l|}
\hline & R Square \\
\hline IG-Score & \\
\hline ISLAMICITY & 0,308 \\
\hline
\end{tabular}

Sources: SmartPLS Output, 2017

From the results of the above output, it can be known that the value of R-Square generated is 0,308 which means that sharia supervisory board (SSB) variable measured by IG-score is able to explain islamicity financial performance index about $30,8 \%$. So that, the effect of SSB on islamicity financial performance index is $30,8 \%$ and the rest $69,2 \%$ is influenced by other variables outside this research model. The second test is to see the significance of the Sharia Supervisory Board's influence on the Islamic financial performance index by looking at the value of parameter coefficients and t-statistical value. The following table presents the value of the coefficient parameters in testing the structural model

Table 13. Path Coefficients of Hypothesis 3

\begin{tabular}{|l|c|c|c|c|c|}
\hline & $\begin{array}{l}\text { Original } \\
\text { Sample } \\
(\mathrm{O})\end{array}$ & $\begin{array}{l}\text { Sample } \\
\text { Mean } \\
(\mathrm{M})\end{array}$ & $\begin{array}{l}\text { Standard } \\
\text { Deviation } \\
(\text { STDEV })\end{array}$ & $\begin{array}{l}\text { T Statistics } \\
(\mid \mathrm{O} / \text { STDEV } \mid)\end{array}$ & P Values \\
\hline $\begin{array}{l}\text { IG-Score } \rightarrow \\
\text { ISLAMICITY }\end{array}$ & 0,555 & 0,570 & 0,100 & 5,563 & 0,000 \\
\hline
\end{tabular}

Sources: Smart PLS Output, 2017

Based on the results of the path coefficients above can be seen that the parameter coefficient is 0,555 which means there is a positive influence of IG-score on islamicity financial performance index. So that, the higher 
the value of IG-score the higher the performance of islamic banks. The value of $t$-statistic generated is higher than t table $(5,563>1,96)$. It means that sharia supervisory board variable has positive and significant effect on islamicity financial performance index. Hence, the third hypothesis is accepted.

\section{Unveiling the Influences}

Based on the results of the PLS output as aforementioned, it can be discussed on the conclusion of islamic social reporting, intellectual capital and sharia supervisory board effect on islamicity financial performance index. The disclosure of social responsibility in Islamic banks is measured by islamic social reporting (ISR) index because it describes social activities according to Islamic concept (Firmansyah, 2014: 55). Social responsibility disclosure shows that islamic bank able to improve society by its social contribution (Sopyan, 2014: 55). After testing the outer and inner model, it can be proven that the values of $\mathrm{t}$-statistic of ISR in the path coefficient table is 9,107 higher than 1,96. In addition, the value of parameter coefficient between ISR and islamicity financial performance index is 0,584 . It concludes that Islamic social reporting has positive and significant effect on Islamicity financial performance index. This indicates that the wider disclosure of islamic social reporting the higher islamic bank's performance that measured by islamicity financial performance index.

Complete and comprehensive information on corporate social responsibility that disclosed by the bank is able to show that the islamic bank has significant contribution in solving the social and environmental problems. Fauzi et al (2007: 157) states that the disclosure of corporate social responsibility (CSR) create a good reputation for the company in the view of stakeholders which have implications on the strengthening of the company's financial position. Involving the disclosure of CSR activities, 
stakeholders who are now increasingly aware of environmental and social issues will see that islamic banks have concerns about environmental conservation and community welfare improvements. This positive image takes influence stakeholder decisions to continue supporting the company. In this case, islamic bank gain stakeholders' trust and also the customers prefer to save their funds or propose credit in islamic bank to other banks. Thus, customer loyalty and other stakeholder support able to increase the revenue of islamic bank so that its financial position increases.

The result of this study is in accordance with the findings of the research conducted by Platonova et al (2016) which shows that social responsibility disclosure has positive and significant impact on the financial performance of the company. Sriviana and Fun (2013) concludes the similar result that the disclosure of social responsibility information is positively correlated with the company's financial performance. It is also in line with the study of Arshad et al (2012) which shows that the disclosure of social responsibility of Islamic concept has positive influence on company performance.

Intellectual capital is the main component of innovation and learning so that the company is able to survive in a strict business competition. Thus, intellectual capital is not only required for companies to survive but also able to achieve superior performance (Dunamis, 2013 in Widyanindyah and Aryani, 2013: 4). Intellectual capital in this study was measured by iB-VAIC ${ }^{\mathrm{TM}}$ consisting of iB-VACA, iB-VAHU and iBSTVA. Based on the results of outer and inner model analysis, it can be proved that the value of $\mathrm{t}$-statistic in the path coefficients table between iBVAIC $^{\mathrm{TM}}$ and Islamicity financial performance index is 7,434 higher than 1,96. In addition, the value of parameter coefficient between $\mathrm{iB}^{\mathrm{V}} \mathrm{VAIC} \mathrm{C}^{\mathrm{TM}}$ and islamicity financial performance index is 0,641 . It concludes that intellectual capital has positive and significant effect on islamicity financial performance index of islamic bank. 
Based on hypothesis testing, it can be concluded that this research is in accordance with the research conducted by Puspitosari (2016), Khasanah (2016) and Ulum (2008) which show that intellectual capital has positive and significant impact on company's financial performance. If a company manages its intellectual capital well, it will have value added that can create a competitive advantage for the company. The results obtained in this study indicate that only valid iB-VACA can explain the ${ }_{i B-V A I C}{ }^{T M}$ construct. In contrast, iB-VAHU and iB-STVA indicator are not valid in explaining iB-VAIC ${ }^{\mathrm{TM}}$ construct. Meanwhile, Islamic financial performance index construct is only explained by the Zakat performance ratio (ZPR) indicator.

The valid component of $\mathrm{iB}-\mathrm{VAIC}^{\mathrm{TM}}$ is only iB-VACA. This shows that islamic banks in Indonesia are successfully utilizing and maximizing physical resources in creating added value. This means that the company's management succeeds in carrying out useful activities for companies such as encouraging employees to innovate and improve business processes in utilizing their own capital to create value for the company (Harianto and Syafruddin, 2013:8). While iB-VAHU and iB-STVA are not valid in explaining $\mathrm{iB}_{\mathrm{B}} \mathrm{VIC} \mathrm{C}^{\mathrm{TM}}$ construct. This shows that the salary, allowances and training provided by islamic banks to their employees have not been able to motivate employees to increase income and profit in the company through skills and knowledge owned by employees (Puspitosari, 2016: 264).

In this study, only iB-VACA as a valid indicator of $\mathrm{iB}^{-V A I C} \mathrm{C}^{\mathrm{TM}}$ construct that has positive and significant impact on islamicity financial performance index which is only explained by ZPR. This shows that intellectual capital can improve the performance of Islamic banks in terms of success in paying zakat. If net assets of Islamic banks are higher, the banks pay higher amount of zakat as well. In this case, the ability of management 
of islamic banks in managing their physical assets owned is able to increase net assets of islamic banks (Harianto and Syafruddin, 2013:9).

In Islamic financial institutions such as islamic banks, corporate governance mechanisms that have monitoring functions besides boards of commissioners and audit committees is sharia supervisory board. Sharia supervisory board is an important part of implementing good corporate governance (GCG) in islamic banks because the duty of this board is to ensure that the banks comply on sharia principles and rules. GCG in a banking management system is designed to improve bank's performance and improve compliance with generally accepted rules and ethical values (Faozan, 2013: 2). According to the results of outer and inner model analysis, it can be proved that the value of t-statistic in the path coefficients table between IG-score and Islamic financial performance index is 5,563 higher than 1,96 . In addition, the value of parameter coefficient between IG-score and islamicity financial performance index is 0,555 . It concludes that shariah supervisory board measured by IG-score, has positive and significant effect on islamicity financial performance index of islamic bank.

Dealing with hypothesis testing, it can be concluded that this study has similar conclusion with the research conducted by Mollah and Zaman (2015) which shows that the sharia supervisory board has positive and significant impact on the performance of Islamic banks. Sharia supervision as the foundation of the governance of islamic banking companies can help Islamic banks in improving better performance. The more the number of sharia supervisory board and the good characteristics of SSB, the better supervision mechanism of islamic bank. This is due to the greater the number of SSB and the higher competence of SSB, the more supervisor that can expand the scope of supervision on activities of Islamic banks so that will be able to increase sharia compliance of the bank. Each member of SSB can perform supervisory functions on different 
aspects of activities. Thus, the increasing number of SSB will be able to make effective supervision that encouraging management to fully comply with Sharia rules and principles in managing the company. If islamic bank comply to sharia rules, it can increase performance of the bank because the possibility of management actions that harm the company can be minimized (Dewayanto, 2010; Andraeny, 2012). This shows that Shariah supervisory boards can improve the performance of islamic banks in the terms of financing with the principle of revenue sharing and distribution of revenue to various stakeholders.

\section{Conclusion}

This paper has successfully examined the factors considered have significant effect on islamicity financial performance index as the measurement of financial performance of islamic bank. The results of the paper proved that islamic social reporting, intellectual capital and sharia supervisory board (SSB) have positive and significant influence on islamicity financial performance index of islamic banks in Indonesia. In means that islamic banks should provide comprehensive information about their CSR activities in the annual report and other media in order to increase financial performance of the bank. In addition, islamic banks are necessary to effectively manage physical resources owned to generate better financial performances. The other important thing is that islamic banks should fully comply with sharia principles in order to maintain the stakeholders' trust that has great effect in achieving good performance of the bank. 


\section{References}

Al-Musali, M. A. K. \& Ismail, K. N. I. K. (2014). Intellectual capital and its effect on financial performance of banks: Evidence from Saudi Arabia. Procedia Social and Behavioral Sciences, 164, pp. 201-207.

Andraeny, D. (2016). Pengungkapan tanggung jawab sosial perusahaan: Studi empiris pada bank syariah di Indonesia. Jurnal EKA CIDA, Vol. 1, No. 1, 55-65.

Andraeny, D. (2012). Analisis pengaruh tata kelola perusahaan dan pengungkapan tanggung jawab sosial perusahaan terhadap kinerja keuangan bank syariah di Indonesia dan Malaysia. Unpublished thesis. Magister Akuntansi, Universitas Jenderal Soedirman.

Arshad, R., Othman, S., \& Othman, R. (2012). Islamic corporate social responsibility, corporate reputation and performance. International Journal of Social Behavioral, Educational, Economic, Business, Industrial Engineering, Vol.6, No. 4, 643-647.

Baehaqi, A. (2014). Usulan model sistem pengawasan syariah pada perbankan syariah di Indonesia. Jurnal Dinamika Akuntansi dan Bisnis, Vol.1, No. 2, 119-133.

Bank Indonesia. (2017). Peraturan Bank Indonesia. Retrieved 10 April 2017. www.bi.go.id.

Budiasih, I. G. A. N. (2015). Intellectual capital dan corporate social responsibility pengaruhnya pada profitabilitas perbankan. Jurnal Dinamika Akuntansi, Vol. 7, No. 1.75-84.

Budisantoso, T. \& Nuritomo. (2014). Bank dan lembaga keuangan lain. Jakarta: Salemba Empat.

Dewayanto, T. (2010). Pengaruh mekanisme good corporate governance terhadap kinerja perbankan nasional. Fokus Ekonomi, Vol. 5, No. 2. $104-123$.

Faozan, A. (2013). Implementasi good corporate governance dan peran 
dewan pengawas syariah di bank syariah. La Riba: Jurnal Ekonomi Islam, Vol.7, No. 1. 1-14.

Farook, S., Hassan, M. K., \& Lanis, R. (2011). Determinants of corporate social responsibility disclosure: The case of islamic bank. Journal of Islamic Accounting and Business Research, Vol. 2, No. 2, 114-141.

Firmansyah, I. (2014). ISR sebagai proksi pengungkapan CSR bank muamalat Indonesia dan bank syariah mandiri. Jurnal Ilmiah ESAI,Vol.8, No. 1, 1-11.

Fitria, S. \& Hartanti, D. (2010). Islam dan tanggung jawab sosial: Studi perbandingan pengungkapan berdasarkan global reporting initiative indeks dan islamic social reporting. Simposium Nasional Akuntansi XIII Purwokerto, Purwokerto.

Hameed, S., Wirman, A., Alrazi, B., Nor, M. N. M. \& Pramono, S. (2004). Alternative disclosure and performance measures for islamic banks. Proceeding of Second Conference on Administrative Science: Meeting The Challenges of The Globalization Age, Saudi Arabia.

Haniffa, R. (2002). Social reporting disclosure an islamic perspective. Indonesian Management \& Accounting Research, Vol.1, No. 2, 128146.

Haniffa, R. \& Hudaib, M. (2007). Exploring the ethical identity of islamic banks via communication in annual reports. Journal of Business Ethics, 76, 97-116.

Haniyah, F. N. \& Priyadi, M. P. (2014). Pengaruh intellectual capital terhadap kinerja perusahaan otomotif di bursa efek Indonesia. Jurnal Ilmu \& Riset Akuntansi, Vol. 3, No. 5, 1-15.

Haryanto, N. \& Syafruddin, M. (2013). Pengaruh modal intelektual terhadap kinerja bisnis bank umum syariah (BUS) di Indonesia. Diponegoro Journal of Accounting, Vol. 2, No. 3, 1-10.

Ilmi, M. B. (2011). Pengaruh zakat sebagai tanggungjawab sosial perusahaan terhadap kinerja perusahaan pada bank syariah di Indonesia. Graduasi, Vol. 26, 10-21. 
Khasanah, A. N. (2016). Pengaruh intellectual capital dan islamicity performance index terhadap kinerja keuangan perbankan syariah di Indonesia. Jurnal Nominal, Vol. 5, No. 6, 1-18.

Kuryanto, B. \& Syafruddin, M. (2009). Pengaruh modal intelektual terhadap kinerja keuangan. Jurnal Akuntansi dan Audit, Vol. 5, No. 2, 128-147.

Meilani, S. E. R., Andraeny, D., \& Rahmayati, A. (2016). Analisis kinerja perbankan syariah di Indonesia dengan menggunakan pendekatan islamicity indices. Proceeding Seminar Nasional dan The 3rd Call for Syariah Paper, Surakarta.

Muhfiatun. (2016). The effect of sharia monetary policy and financing quality on financial performance in sharia banking. Shirkah Journal of Economics and Business Vol. 1 No.3, 2016.

Mollah, S. \& Zaman, M. (2015). Shari'ah supervision, corporate governance and performance: Conventional vs islamic bank. Journal of Banking \& Finance, 58, 418-435.

Nurhudha, A. S. \& Suwarti, T. (2014). Analisis pengaruh corporate social responsibility, intellectual capital, dan kinerja lingkungan terhadap kinerja keuangan perusahaan manufaktur yang terdaftar di bursa efek Indonesia. Prosiding Seminar Nasional Multi Disiplin Ilmu \& Call for Papers UNISBANK, Semarang.

OJK. (2017). Sharia banking statistic 2017. Retrieved 10 April 2017. www. ojk.go.id.

Othman, R., Thani, A. M. \& Ghani, E. K. (2009). Determinants of islamic social reporting among top shariah--approved companies in bursa Malaysia. Research Journal International Studies 12. 4-20.

Ousama, A. A. \& Fatima, A. H. (2015). Intellectual capital and financial performance of islamic banks. International Journal Learning Intellectual Capital, Vol.12, No. 1. 1-15.

Platonova, E., Asutay, M., Dixon, R., \& Mohammad, S. (2016). The impact of corporate social responsibility disclosure on financial 
performance: Evidence from the GCC islamic banking sector. Journal of Business Ethics. July, 1-21.

Prastya, O. M. (2013). Pengaruh modal intelektual dan tata kelola perusahaan terhadap kinerja keuangan. Jurnal Ilmu Manajemen, Vol.1, No. 3, 677-689.

Puspitosari, I. (2016). Modal intelektual dan kinerja keuangan dengan menggunakan islamicity performance index pada bank umum syariah. Hunafa: Jurnal Studia Islamika, Vol. 13, No. 2, 248-270.

Santoso, S. (2012). Pengaruh modal intelektual dan pengungkapannya terhadap kinerja perusahaan," Jurnal Akuntansi dan Keuangan, Vol.14, No. 1, 16-31.

Satifa, O. \& Suprapto, E. (2014). Peran dewan pengawas syariah dalam pemenuhan prinsip syariah dalam pelaksanaan good corporate governance pada perbankan syariah. Jurnal Ekonomi dan Perbankan Syariah Vol. 2, No. 2. 69-93.

Satiti, A. \& Asyik, N. F. (2013). Pengaruh intellectual capital terhadap kinerja keuangan perusahaan asuransi. Jurnal Ilmu \& Riset Akuntansi, Vol. 2, No. 7. 1-20.

Sawarjuwono, T. \& Kadir, A. P. (2003). Intellectual capital: Perlakuan, pengukuran dan pelaporan. Jurnal Akuntansi dan Keuangan, Vol. 5, No. 1, 35-57.

Sidik, I. \& Reskino. (2016). "Pengaruh zakat dan ICSR terhadap reputasi dan kinerja,” Paper Simposium Nasional Akuntansi XIX, Lampung.

Sriviana, E. \& Asyik, N. F. (2013). Pengaruh pengungkapan corporate social responsibility dan ukuran perusahaan terhadap profitabilitas. Jurnal Ilmu dan Riset Akuntansi, Vol. 2, No. 4. 1-16.

Sumedrea, S. (2013). Intellectual capital and firm performance: A dynamic relationship in crisis time. Procedia Economics and Finance, 6, 137144. 
Syukron, A. (2013). Good corporate governance di bank syariah. Jurnal Ekonomi dan Hukum Islam, Vol. 3, No. 1, 60-83.

Ulum, I. (2013). Model pengukuran kinerja intellectual capital dengan iB-VAIC di perbankan syariah. INFERENSI Jurnal Penelitian Sosial Keagamaan, Vol. 7,Vol. 1, 185-206.

Wahyuni, S. \& Pujiharto. (2015). Mengukur kinerja intellectual capital dengan model iB-VAIC: Implementasi resources based theory pada perbankan syariah di Indonesia. Paper Seminar Nasional dan The 3rd Call for Syariah Paper, Surakarta.

Wardani, E. A. (2015). Pengaruh islamic corporate social responsibility disclosure terhadap reputasi perusahaan dan kinerja keuangan perusahaan. Paper Simposium Nasional Akuntansi 18, Medan.

Widyaningdyah, A. U. \& Aryani, Y. A. (2013). Intellectual capital dan keunggulan kompetitif. Jurnal Akuntansi dan Keuangan, Vol. 15, No. 1, 1-14.

Yaparto, M., Frisko, D., \& Eriandani, R. (2013). Pengaruh corporate social responsibility terhadap kinerja keuangan pada sektor manufaktur yang terdaftar di bursa efek Indonesia pada periode 2010-2011. Jurnal Ilmiah Mahasiswa Universitas Surabaya, Vol. 2, No. 1, 1-19.

Anwar, M. (2003). Islamicity of banking and modes of Islamic banking. Arab Law Quarterly 18(1), 62-80.

Rehman, S.S., Askari, H. (2010). An economic Islamicity Index (EI2). Global Economy Journal. Volume 10, Issue 3, 6 October, Article number 1 . 
Vol. 2 No. No. 3, September - December 2017 
Vol. 2 No. No. 3, September - December 2017 


\section{Shirkah Author Guidelines}

Shirkah currently offers two routes to submit manuscripts. We highly recommend to submit the articles which are made using OJS (Open Journal System). Feel free register as author soon through visiting http:// shirkah.or.id/index.php/home/user/register. The authors may directly send their manuscripts, along with their resume, to shirkahiainsurakarta@ gmail.com. Please prepare your manuscripts, using following guidelines:

1. Manuscript must be written in English. Submitted articles should not have been published or be under review for publication with another journal.

2. Manuscript's length is about $15-20$ pages, typed in one-half spaced on A4-paper size.

3. Manuscript must include an $150-200$ word abstract and keywords.

4. Manuscript must be arranged as follows: Title, Name of Author, E-mail address, Abstract, Keywords, Introduction (including method if any), Discussion, Conclusion, References.

5. Manuscript's titles not more than ten words.

6. Manuscript must be submitted in Microsoft Word or RTF.

7. Arabic words should be transliterated according to the style of International Journal of Middle Eastern Studies.

8. Manuscript references are preferably derived from the up-to-date references.

9. The author's resume should be submitted separately, consisting of at least full name, institutional address, phone number, areas of studies, and recent publications (if any).

10. Shirkab use APA Style 6th edition (2010) as reference format writing. We suggest the use of a reference manager software such as Mendeley, Zotero, and Endnote at templating the citation style. APA Style to be used is as follows: 


\section{Book with single author}

Swann, G. M. Peter. (2014). The Economics of Innovation an Introduction. Cheltenhum \& Northampton: Edward Elgar.

in-text citation: (Swann, 2014)

\section{Articles in reference books}

Alatas, S. F. (2006). Islam and the Science of Economics in Abu Rabi', I.M. The Blackwell Companion to Contemporary Islamic Thought. USA: Willey-Blackwell (pp. 587-606).

in text citation: (Alatas, 2006)

\section{E-Book}

Hackett, Rosalind (2007). "Religous Dimentions of War and Peace: Introduction." Dalam Gerrie ter Haar dan Yoshio Tsuruoka (Ed.), Religion and Society: An Agenda for the 21st Century (h. 3-6). Retrieved from http:// brill.nl.

in text citation: (Hackett, 2006)

\section{Master's thesis, from a commercial database}

McNieI, D. S. (2006). Meaning through narrative: A personal narrative discussing growing up with an alcoholic mother (Master's thesis). Available from ProQuest Dissertations and Theses database. (UMI No. 1434728)

in text citation: (Mc Niel, 2006)

\section{Doctoral dissertation, from an institutional database}

Adams, R. J. (1973). Building a foundation for evaluation of instruction in higher education and continuing education (Doctoral dissertation). Retrieved from http://www.ohiolink.edu/etd/

in text citation: (Adams, 1973) 


\section{Doctoral dissertation, from the web}

Bruckman, A. (1997). MOOSE Crossing: Construction, community, and learning in a networked virtual world for kids (Doctoral dissertation, Massachusetts Institute of Technology). Retrieved from http:/www-static. cc.gatech.edu/--asb/thesis/

in text citation: (Bruckman, 1997)

\section{Journal article with No DOI}

Bourkhis, K., and Nabi, M. S. (2013). Islamic and conventional banks' soundness during the 2007-2008 financial crisis. Journal Metrics, 22(2), 68-77.

in-text citation: (Bourkhis \& Nabi, 2013).

\section{Journal article with DOI}

Ichwan, M. (2012). The Local Politics Of Orthodoxy: The Majelis Ulama Indonesia in the Post-New Order Banten. Journal Of Indonesian Islam, 6(1), 166-194. doi:http://dx.doi.org/10.15642/JIIS.2012.6.1.166-194

In text citation : (Ichwan, 2012)

\section{Abstract as citation}

Hasan, N. (2012). Islamist Party, Electoral Politics And Da'wah Mobilization Among Youth : The Prosperous Justice Party (PKS) in Indonesia. Journal of Indonesian Islam, 6(1), 17-47. Abstract from http:// jiis.uinsby.ac.id/index.php/jiis/article/view/97

in text citation : (Hasan, 2012)

\section{Mass media article}

Sahal, Akhmad (2014, March 2). Kiai Sahal dan Realisme Fikih.Tempo Magazine, p. 120.

in text citation : (Sahal, 2014) 


\section{Research report}

Fisher, B. S., Cullen, F. T., \& Turner, M. G. (2000). The Sexual Victimization of College Women. Research Report.

in text citation : (Fisher, Cullen, Turner, 2000)

\section{Monograph}

Routray, Bibhu Prasad (2013), National Security Decision-Making in India (RSIS Monograph No. 27). Singapura: Rajaratnam School of International Studies.

in text citation : (Routray, 2013)

\section{Proceeding article}

Sudibyakto, Hizbaron, D.R., \& Jati, R (Ed.) (2009), Proceeding International Seminar Disaster Theory, Research and Policy. International seminar held by Sekolah Pascasarjana, Universitas Gajahmada, Yogyakarta, 8-9 Desember 2009.

in text citation : (sudibyakto and Jati, 2009)

\section{Paper conference/seminar/symposium}

Janutama, Herman Sinung (2011). "Kraton dan Hubungan Antar Agama." Paper presented in Seminar Kraton dan Panatagama held by Center for the Study of Islam and Social Transformation (CISForm), Yogyakarta, 17 November.

in text citation :(Janutama, 2011)

\section{Online article in web}

Shiva, (2006, February). Bioethics: A Third World Issue. Native-web. Diperoleh dari http://www.nativeweb.org/ pages/legal/shiva.html 
in text citation : (Shiva, 2006)

\section{Online research report}

Kessy, S. S. A., \& Urio, F M. (2006). The contribution of microfinance institutions to poverty reduction in Tanzania (Research Report No. 06.3). Retrieved from Research on Poverty Alleviation website: http://www. repoa.or.tz /documents_storage/Publications/Reports/06.3_Kessy_and_ Urio.pcif

in text citation : (kessy and urion, 2006)

\section{Holy book}

Qur an, $2(25)$

In text citation : (Q. al-Baqarah 2:25).

\section{Encyclopaedia}

Graycar, Adam (1992). Social Welfare Policy. Dalam Mary Hawkesworth dan Maurice Kogan (Ed.), Encyclopedia of Government and Politics (Vol. 1). London: Routledge.

in text citation : (Graycar, 1992)

\section{Interview}

Sultan Hamengkubuwono X (interview, 2011, April 19)

in text citation : (Hamengkubuwono, 2011)

\section{Documentary film}

Steijlen, Fridus (2008). A Day in the Life of Indonesia [documentary film, 58 minutes]. Leiden: KITLV Press.

in text citation : (Steijlen, 2008) 
Vol. 2 No. No. 3, September - December 2017 